\author{
RESEARCHPAPER
}

\title{
Binding pattern determination for class of anti-alzheimer's compound
}

\author{
VINEETA GURNANI, PRATEEK SINGH, ARADHANA IRENE CHARAN AND AMIT ALEXANDER \\ CHARAN
}

Department of Molecular and Cellular Engineering, Sam Higginbottom Institute of Agriculture, Technology and Sciences, ALLAHABAD (U.P.) INDIA

Email : gurnanivinita@yahoo.co.in

Article Info :Received : 05.12.2015; Revised : 11.01.2016; Accepted : 08.02 .2016

\begin{abstract}
Alzheimer's disease (AD) is the most common form of dementia. No cure has been observed for the disease, and it worsens as it progresses, which eventually leads to death. It is believed that some plaques and tangles develop within the structure of the brain which causes brain cells to die. Alzheimer's patients also have a deficiency of neurotransmitters which ultimately hampers the transmission of messages in the brain. It was confirmed by Amyloid hypothesisthat beta-amyloid ( $\beta \mathrm{A})$ deposits are the fundamental cause of the disease. So, in this research natural and synthetic compounds were selected on the basis of their binding or inhibition to the amyloid precursor protein (APP). The protein and the ligands were optimized, docked and their interaction was visualized on the basis of binding energy.
\end{abstract}

Key words : Alzheimer's, Amyloid, Docking, Binding energy

How to cite this paper : Gurnani, Vineeta, Singh, Prateek, Charan, Aradhana Irene and Charan, Amit Alexander (2016). Binding pattern determination for class of anti-alzheimer's compound. Asian J. Bio. Sci., 11 (1) : 66-70 [Special Issue of AFBSAH-2016]. 